\title{
PENGARUH KOMPETENSI DAN KOMPENSASI TERHADAP MOTIVASI KERJA DI PT HAMATETSU INDONESIA
}

\author{
Sihabudin \\ Universitas Buana Perjuangan Karawang \\ sihabudin@ubpkarawang.ac.id
}

\begin{abstract}
ABSTRAK
Masalah yang diangkat dalam penelitian ini adalah : untuk mengetahui, menjelaskan dan menganalisis Kompetensi, Kompensasi dan Motivasi Kerja karyawan pada PT Hamatetsu Indonesia. Menjelaskan hubungan Kompetensi dan Kompensasi, menjelaskan besaran pengaruh kompetensi terhadap motivasi kerja, menjelaskan besaran pengaruh kompensasi terhadap motivasi kerja baik parsial maupun simultan. Penelitian ini menggunakan analisis jalur (Path Analysis), yaitu menganalisis mengenai hubungan kausal dengan tujuan memisahkan pengaruh langsung dan pengaruh tidak langsung suatu variabel penyebab terhadap variabel akibat. Jumlah sampel yang diambil 186 responden dengan teknik Probability Sampling dengan teknik sampling berdasarkan tingkatan. Penelitian ini ini diharapkan dapat memberikan sumbangan bagi pengembangan bidang manajemen khususnya manajemen sumber daya manusia. Metode penelitian yang digunakan penulis dalam penulisan ini menggunakan metode deskriptif dan verifikatif, dari hasil analisis data penelitian diperoleh beberapa kesimpulan sebagai berikut : (1) Variabel Kompetensi (X1) sebesar 649.5 atau berada pada skala setuju. Pada variabel kompetensi terdapat 3 indikator yang berada pada kriteria cukup setuju yaitu indikator pengetahuan teknis, kondisi kerja dan aktifitas kerja; (2) Variabel Kompensasi (X2) sebesar 622.9 atau berada pada kriteria cukup setuju. Pada variabel kompensasi terdapat 2 indikator yang berada pada kriteria tidak setuju yaitu indikator tunjangan kesehatan dan asuransi; (3) Variabel Motivasi kerja (Y) sebesar 653.2 atau berada pada kriteria setuju. Pada variabel motivasi kerja terdapat 3 indikator yang berada pada kriteria cukup setuju yaitu resiko kerja, kerja kelompok, pengaruh dan kekuasaan;
\end{abstract}


(4) Kompetensi (X1) secara parsial terhadap Motivasi kerja (Y) dengan tingkat signifikan $(\alpha)=5 \%$ menunjukan bahwa $t_{\text {hitung }}=6.255$ dan Sig. $(0.000)<\alpha(0.05)$ dan thitung (6.255) > ttabel (1.973), maka Ho ditolak; (5) Kompensasi (X2) secara parsial terhadap Motivasi kerja $(Y)$ tingkat signifikan $(\alpha)=5 \%$ menunjukan bahwa thitung $=4.600$ dan Sig. $(0.000)<\alpha(0.05)$ dan thitung $(4.600)>t_{\text {tabel }}(1.973)$, maka $H_{0}$ ditolak; (6) Kompetensi (X1) dan Kompensasi (X2) secara simultan terhadap Motivasi kerja dengan tingkat signifikan $(\alpha)=5 \%$ menunjukan bahwa nilai Sig. $(0.000)<\alpha(0.05)$ dan $f_{\text {hitung }}(189.906)>f_{\text {tabel }}(3.04)$, maka $H_{0}$ ditolak.

Kata Kunci : Kompetensi, Kompensasi, Motivasi Kerja Karyawan

\section{A. PENDAHULUAN}

Dunia bisnis sekarang persaingan antar perusahaan semakin tajam, sehingga sumber daya manusia dituntut untuk terus menerus mampu mengembangkan diri secara proaktif. Sumber daya manusia harus menjadi manusia-manusia pembelajar, yaitu pribadi-pribadi yang mau belajar dan bekerja keras dengan penuh semangat, sehingga potensi insaninya berkembang maksimal. Oleh karena itu, sumber daya manusia yang diperlukan pada saat ini adalah sumber daya manusia yang sanggup menguasai teknologi dengan cepat, adaptif, dan responsif terhadap perubahan-perubahan teknologi. Dalam kondisi tersebut integritas pribadi semakin penting untuk memenangkan persaingan.

Menurut Hasibuan (2013:110) Motivasi adalah gairah kerja bawahannya agar mau bekerja keras dengan memberikan semua kemampuan dan keterampilan untuk mewujudkan tujuan perusahaan.

Menurut Mondy Wayne (2008:442) kompensasi merupakan hal yang penting dan merupakan dorongan motivasi utama seorang karyawan untuk bekerja hal ini berarti bahwa karyawan menggunakan pengetahuan, keterampilan, tenaga dan waktu bukan semata-mata ingin mengabdikan diri pada perusahaan tetapi ada tujuan lain yaitu mengharapkan imbalan atau balas jasa atas hasil yang telah diberikan.

Dalam penelitian ini peneliti meneliti tentang keterkaitan kompetensi dan kompensasi. Jika kompetensi baik dan kompensasi baik maka motivasi kerja karyawan akan meningkat. Kompensasi merupakan hal yang penting dan merupakan dorongan motivasi utama seorang karyawan untuk bekerja. Jadi pada 
dasarnya apabila perusahaan ingin motivasi karyawannya meningkat maka perusahaan haruslah memberikan kompensasi yang layak. Dengan begitu karyawan akan termotivasi dan bekerja lebih semangat demi mencapai target perusahaan.

\section{B. LANDASAN TEORI}

\section{Pengertian Manajemen}

Manajemen berasal dari kata to manage yang artinya mengatur. Pengaturan dilakukan melalui proses dan diatur berdasarkan urutan dari fungsi-fungsi manajemen itu. Jadi, manajemen itu merupakan suatu proses untuk mewujudkan tujuan yang diinginkan. Menurut Malayu S.P. Hasibuan (2009:2) "Manajemen adalah ilmu dan seni yang mengatur proses pemanfaatan sumber daya manusia dan sumber-sumber daya lainnya secara efektif dan efisien untuk mencapai suatu tujuan tertentu."

\section{Pengertian Manajemen Sumber Daya Manusia}

Manajemen sumber daya manusia adalah ilmu dan seni mengatur hubungan dan peranan tenaga kerja agar efektif dan efisien membantu terwujudnya tujuan perusahaan, karyawan, dan masyarakat. Menurut Simamora (dalam Edy Sutrisno, 2012:5) "Manajemen sumber daya manusia adalah pendayagunaan, pengembangan, penilaian, pemberian balas jasa, dan pengelolaan individu anggota organisasi atau kelompok pekerja."

\section{Pengertian Kompetensi}

Menurut Scale (dalam Edy Sutrisno, 2012:202) Kompetensi berasal dari kata competence yang artinya kecakapan, kemampuan, dan wewenang. Adapun secara etimologi, kompetensi diartikan sebagai dimensi perilaku keahlian atau keunggulan seorang pemimpin atau staf mempunyai keterampilan, pengetahuan, dan perilaku yang baik. 
Menurut Spencer dan Spencer (dalam Edy Sutrisno, 2012:202) Kompetensi adalah suatu yang mendasari karakteristik dari suatu individu yang dihubungkan dengan hasil yang diperoleh dalam suatu pekerjaan.

Menurut Boulter, Dalzier, dan Hill (dalam Edy Sutrisno, 2012:203) Kompetensi adalah suatu karakteristik dasar dari seseorang yang memungkinkan nya memberikan kinerja unggul dalm pekerjaan, peran, atau situasi tertentu.

\section{Pengertian Kompensasi}

Menurut Malayu Hasibuan (2013:118), Kompensasi adalah semua pendapatan yang berbentuk uang, barang langsung atau tidak langsung yang diterima karyawan sebagai imbalan atas jasa yang diberikan kepada perusahaan.

Menurut Tohardi (dalam Edy Sutrisno, 2012:182)

"Mengemukakan bahwa kompensasi dihitung berdasarkan evaluasi pekerjaan, perhitungan kompensasi berdasarkan evaluasi pekerjaan tersebut dimaksudkan untuk mendapatkan pemberian kompensasi yang mendekati kelayakan (worth) dan keadilan (equity)."

Menurut Andrew F. Sikula (dalam Malayu Hasibuan, 2013:119) Kompensasi adalah segala sesuatu yang dikonstitusikan atau dianggap sebagai suatu balas jasa atau ekuivalen.

\section{Pengertian Motivasi Kerja}

Menurut Hasibuan (2010:92) Mengemukakan motivasi berasal dari kata latin movere yang berarti menggerakan atau mendorong. Didalam konsep manajemen atau konsep manajemen perilaku kata motivasi didefinisikan sebagai semua upaya untuk memunculkan dari dalam semangat orang lain (bawahan) agar mau bekerja keras guna mencapai tujuan organisasi melalui pemberian atau penyediaan pemuasan kebutuhan mereka. Seorang manajer harus mengenal konsep motivasi agar manajer juga memahami bahwa bawahan juga orang (manusia) seperti dirinya yang 
mempunyai martabat, harga diri, kepribadian, emosi, keyakinan, kepercayaan, keinginan, dan harapan.

Menurut Hasibuan (2010:95) "Motivasi adalah pemberian daya penggerak yang menciptakan kegairahan kerja seseorang agar mereka mau bekerja sama, bekerja efektif, dan terintegrasi dengan segala daya upayanya untuk mencapai kepuasan."

Menurut Stephen P. Robbins, dkk (1999) dalam Winardi (2011:2)“Motivasi adalah kesediaan untuk melaksanakan uapaya tinggi untuk mencaapai tujuan-tujuan keorganisasian, yang dikondisikan oleh kemampuan upaya untuk memenuhi kebutuhan individual tertentu."

\section{METODE PENELITIAN}

\section{Desain Penelitian}

Berdasarkan hasil penelitiannya desain penelitian ini merupakan penelitian survey dimana peneliti terjun langsung ke lapangan untuk memperoleh data dengan cara wawancara atau mengisi kuesioner.

\section{Variabel Penelitian}

\section{Tabel 3.1}

\section{Instrumen Penelitian}

\begin{tabular}{|c|c|c|}
\hline Variabel & Dimensi & Indikator \\
\hline \multirow{6}{*}{$\begin{array}{l}\text { Kompetensi* } \\
\text { (X1) }\end{array}$} & \multirow{2}{*}{$\begin{array}{l}\text { 1. Pengetahuan } \\
(\text { knowledge })\end{array}$} & 1. Pengetahuan tentang teknis pekerjaan. \\
\hline & & 2. Pengetahuan tentang prosedur pekerjaan. \\
\hline & \multirow{2}{*}{$\begin{array}{l}2 . \quad \text { Pemahaman } \\
\text { (understanding) }\end{array}$} & $\begin{array}{l}\text { 1. Pemahaman yang baik tentang } \\
\text { karakteristik. }\end{array}$ \\
\hline & & 2. Kondisi kerja secara efektif dan efesien. \\
\hline & 3. Kemampuan (skill) & $\begin{array}{l}\text { 1. Kemampuan karyawan dalam memilih } \\
\text { metode kerja yang efektif dan efesien. }\end{array}$ \\
\hline & 4. Nilai (value) & 1. Kejujuran. \\
\hline
\end{tabular}




\begin{tabular}{|c|c|c|}
\hline & & 2. Keterbukaan. \\
\hline & & 3. Demokrasi. \\
\hline & & 1. Penampilan. \\
\hline & J. गाкар (älumaе) & 2. Perilaku. \\
\hline & 6. Minat (interest) & 1. Melakukan suatu aktivitas kerja. \\
\hline & & 1. Gaji. \\
\hline & & 2. Upah. \\
\hline & & 3. Insentif \\
\hline & 1. Kumpensast 1angsung & 4. Tunjangan kesehatan. \\
\hline & & 5. Tunjangan transportasi. \\
\hline Kompensasi** & & 6. Tunjangan keluarga. \\
\hline$(\mathrm{X} 2)$ & & 1. Asuransi. \\
\hline & & 2. Fasilitas perusahaan. \\
\hline & 2. Kompensasi tidak & 3. Tunjangan hari raya. \\
\hline & langsung & 4. Uang pensiun. \\
\hline & & 5. Pakaian dinas. \\
\hline & & 6. Darmawisata (family gathering). \\
\hline & 1. Need for achievement & $\begin{array}{l}\text { 1. Memiliki tingkat tanggung jawab pribadi } \\
\text { yang tinggi. }\end{array}$ \\
\hline & (kebutuhan untuk & 2. Berani mengambil dan memikul resiko. \\
\hline & mencapai prestasi). & 3. Memiliki tujuan yang realistik. \\
\hline & & 4. Memiliki rencana kerja. \\
\hline & 2. Need for & 1. Bersifat sosial dan suka berinteraksi. \\
\hline & $\begin{array}{l}\text { affiliation(kebutuhan } \\
\text { untuk memperluas }\end{array}$ & $\begin{array}{l}\text { 2. Ikut memiliki dan berpatisipasi dengan } \\
\text { kelompok. }\end{array}$ \\
\hline & pergaulan) & 3. Menginginkan kepercayaan lebih luas. \\
\hline
\end{tabular}




\section{Tabel 3.1(Lanjutan)}

\section{Instrumen Penelitian}

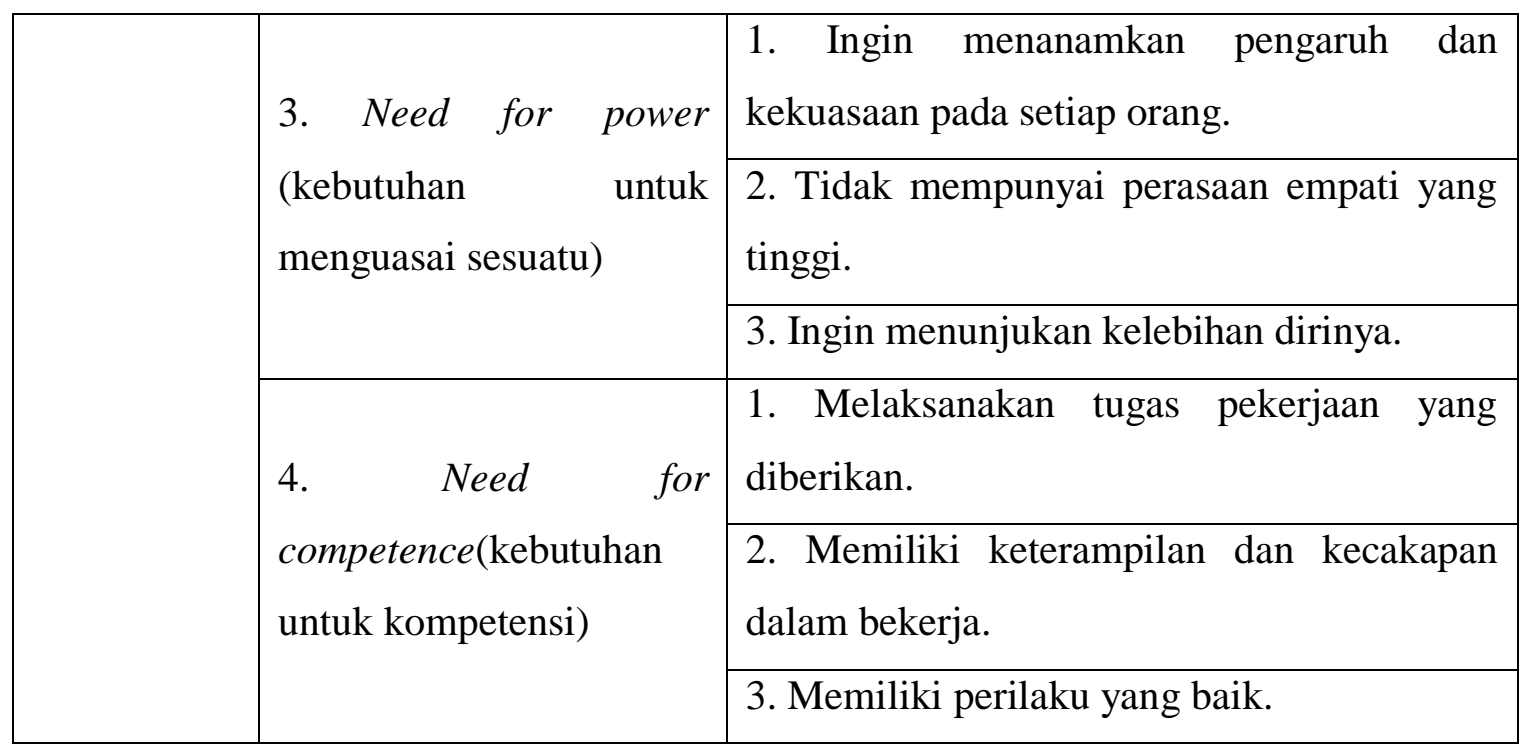

Sumber : * Gordon (1988) dalam Edy Sutrisno (2012:204-205)

** Veithzal Rivai (2006:360)

*** David McClelland (1974) dalam Malayu Hasibuan (2010:97)

\section{Metode Pengumpulan Data}

\section{1) Populasi, Sampel, dan Teknik Sampling}

a. Populasi

Populasi dalam penelitian ini merupakan seluruh karyawan PT Hamatetsu Indonesia yang berjumlah 400 orang.

b. Sampel

Sampel dalam penelitian ini berjumlah 186 orang, Penentuan jumlah sampel dari populasi tertentu dengan menggunakan rumus Isaac dan Michael dalam Sugiyono (2011:86-87). Rumus Pengambilan Sampel

\footnotetext{
$\lambda^{2} \cdot \mathbf{N} \cdot \mathbf{P} \cdot \mathbf{Q}$$$
s=\frac{d^{2}(N-1)+\lambda^{2}-P Q}{d^{2}-P_{111}}
$$$$
\text { Dimana : } \quad v-\text { Jumsan sampus (viang) }
$$$$
\lambda^{2}=\text { dengan } \mathrm{dk}=1
$$$$
\text { taraf kesalahan sampai } 1 \%, 5 \% \text {, dan } 10 \%
$$ 


$$
\begin{aligned}
& \mathrm{P}=\mathrm{Q}=0,5 \text { dan } \mathrm{d}=0,05 \\
& \mathrm{~N}=\text { Populasi }
\end{aligned}
$$

\section{Gambar 3.1}

\section{Rumus Isaac dan Michael}

Sumber : Sugiyono (2011:86-87)

c. Teknik Sampling

Teknik sampling merupakan teknik pengambilan sampel. Untuk mendapatkan sample yang lebih representative, Maka Teknik pengambilan sampel menggunakan metode Disproportionate Stratified Random Sampling. Menurut Riduwan dan Engkos Achmad Kuncoro (2012:42) Disproportionate Stratified Random Sampling yaitu Pengambilan Sampel dari anggota populasi secara acak dan berstrata tetap sebagian yang kurang porposional pembagiannya, dilakukan sampling ini apabila anggota populasi heterogen (tidak sejenis).

\section{HASIL PENELITIAN DAN PEMBAHASAN}

\section{Rekapitulasi Variabel Kompetensi}

Berikut ini adalah hasil rekapitulasi variabel Kompetensi PT Hamatetsu Indonesia.

\section{Tabel 4.1}

\section{Rekapitulasi Indikator Variabel Kompetensi $\left(\mathbf{X}_{1}\right)$}

\begin{tabular}{|l|l|l|l|}
\hline No & Indikator & $\begin{array}{l}\text { Total } \\
\text { Skor }\end{array}$ & Keterangan \\
\hline 1 & Pengetahuan Tentang Teknis & 624 & Cukup Setuju \\
\hline 2 & Pengetahuan Tentang Prosedur & 651 & Setuju \\
\hline 3 & Pemahaman Karakteristik & 642 & Setuju \\
\hline 4 & Kondisi Kerja & 624 & Cukup Setuju \\
\hline 5 & Kemampuan Karyawan & 678 & Setuju \\
\hline 6 & Kejujuran & 646 & Setuju \\
\hline
\end{tabular}




\begin{tabular}{|l|l|l|l|}
\hline 7 & Keterbukaan & 672 & Setuju \\
\hline 8 & Demokrasi & 675 & Setuju \\
\hline 9 & Penampilan & 648 & Setuju \\
\hline 10 & Perilaku & 655 & Setuju \\
\hline 11 & Aktifitas Kerja & 630 & Cukup Setuju \\
\hline & Total & $\mathbf{7 1 4 5}$ & \\
\hline & Rata-rata Skor & $\mathbf{6 4 9 , 5}$ & Setuju \\
\hline
\end{tabular}

Sumber : Hasil Pengolahan Data, 2015

Berdasarkan tabel 4.1 jumlah skor seluruh indikator variabel Kompetensi sebesar 7145 dengan Rata-rata 649,5.

\section{Rekapitulasi Variabel Kompensasi}

Berikut ini adalah hasil rekapitulasi variabel Kompensasi PT Hamatetsu Indonesia.

\section{Tabel 4.2}

\section{Rekapitulasi Indikator Variabel Kompensasi $\left(\mathbf{X}_{2}\right)$}

\begin{tabular}{|l|l|l|l|}
\hline No & Indikator & $\begin{array}{l}\text { Total } \\
\text { Skor }\end{array}$ & Keterangan \\
\hline 1 & Gaji & 631 & Cukup Setuju \\
\hline 2 & Upah & 657 & Setuju \\
\hline 3 & Insentif & 651 & Setuju \\
\hline
\end{tabular}

\section{Tabel 4.2}

\section{Rekapitulasi Indikator Variabel Kompensasi (X2)(Lanjutan)}

\begin{tabular}{|l|l|l|l|}
\hline 4 & Tunjangan Kesehatan & 479 & Tidak Setuju \\
\hline 5 & Tunjangan Transportasi & 674 & Setuju \\
\hline 6 & Tunjangan Keluarga & 639 & Setuju \\
\hline 7 & Asuransi & 474 & Tidak Setuju \\
\hline
\end{tabular}




\begin{tabular}{|l|l|l|l|}
\hline 8 & Fasilitas perusahaan & 656 & Setuju \\
\hline 9 & Tunjangan Hari Raya & 645 & Setuju \\
\hline 10 & Uang Pensiun & 655 & Setuju \\
\hline 11 & Pakaian Dinas & 638 & Setuju \\
\hline 12 & Darmawisata & 676 & Setuju \\
\hline & Total & $\mathbf{7 4 7 5}$ & \\
\hline & Rata-rata Skor & $\mathbf{6 2 2 , 9}$ & Cukup Setuju \\
\hline
\end{tabular}

Sumber : Hasil Pengolahan Data, 2015

Berdasarkan tabel 4.2 jumlah skor seluruh indikator variabel Kompensasi sebesar 7475 dengan Rata-rata 622,9.

\section{Rekapitulasi Variabel Motivasi Kerja}

Berikut ini adalah hasil rekapitulasi variabel Motivasi Kerja PT Hamatetsu Indonesia.

\section{Tabel 4.3}

\section{Rekapitulasi Indikator Variabel Motivasi Kerja (Y)}

\begin{tabular}{|l|l|l|l|}
\hline No & Indikator & $\begin{array}{l}\text { Total } \\
\text { Skor }\end{array}$ & Keterangan \\
\hline 1 & Tanggung Jawab & 668 & Setuju \\
\hline 2 & Resiko & 628 & Cukup Setuju \\
\hline 3 & Memiliki Tujuan & 651 & Setuju \\
\hline 4 & Rencana Kerja & 643 & Setuju \\
\hline 5 & Bersifat Sosial & 674 & Setuju \\
\hline 6 & Kerja Kelompok & 619 & Cukup Setuju \\
\hline 7 & Kepercayaan & 673 & Setuju \\
\hline 8 & Pengaruh dan kekuasaan & 628 & Cukup Setuju \\
\hline 9 & Empati & 680 & Setuju \\
\hline 10 & Kelebihan Diri & 662 & Setuju \\
\hline 11 & Melaksanakan Pekerjaan & 651 & Setuju \\
\hline 12 & Keterampilan dan Kecakapan & 659 & Setuju \\
\hline
\end{tabular}




\begin{tabular}{|l|l|l|l|}
\hline 13 & Perilaku & 656 & Setuju \\
\hline & Total & $\mathbf{8 4 9 2}$ & \\
\hline & Rata-rata Skor & $\mathbf{6 5 3 , 2}$ & Setuju \\
\hline
\end{tabular}

Sumber : Hasil Pengolahan Data, 2015

Berdasarkan tabel 4.3 jumlah skor seluruh indikator variabel Motivasi Kerja sebesar 8492 dengan Rata-rata 653,2.

\section{Path Analysis}

Hubungan antara variabel bebas disajikan dalam tabel 4.4 dibawah ini :

\section{Tabel 4.4}

\section{Korelasi Variabel Bebas}

Correlations

\begin{tabular}{|ll|l|l|}
\hline & & Kompetensi & Kompensasi \\
\hline Kompetensi & Pearson Correlation & 1 & $.845^{* *}$ \\
& Sig. (2-tailed) & & .000 \\
& $\mathrm{~N}$ & 186 & 186 \\
\hline Kompensasi & Pearson Correlation & $.845^{* *}$ & 1 \\
& Sig. (2-tailed) & .000 & \\
& $\mathrm{~N}$ & 186 & 186 \\
\hline
\end{tabular}

**. Correlation is significant at the 0.01 level (2-tailed).

Sumber : Hasil Pengolahan Data, 2015

Berdasarkan hasil pengolahan data denganan bantuan software SPSS 16.Didapatkan koefesien jalur untuk setiap variabel Kompetensi $\left(\mathrm{X}_{1}\right)$, Kompensasi $\left(\mathrm{X}_{2}\right)$ terhadap Motivasi Kerja (Y). Hasil analisis tersebut dapat dilihat pada tabel berikut ini: 


\section{Tabel 4.5}

\section{Koefisien Jalur}

Coefficients $^{\mathrm{a}}$

\begin{tabular}{|ll|l|l|l|l|l|}
\hline \multicolumn{2}{|l|}{ Model } & \multicolumn{2}{|l|}{\begin{tabular}{l} 
Unstandardized \\
\multicolumn{2}{|l|}{ Coefficients }
\end{tabular}} & $\begin{array}{l}\text { Standardized } \\
\text { Coefficients }\end{array}$ & $\mathrm{T}$ & \multirow{2}{*}{ Sig. } \\
\cline { 2 - 5 } & $\mathrm{B}$ & Std. Error & Beta & \\
\hline 1 & (Constant) & 6.058 & 2.153 & & 2.814 & .005 \\
& Kompetensi & .636 & .102 & .492 & 6.255 & .000 \\
& Kompensasi & .409 & .089 & .362 & 4.600 & .000 \\
\hline
\end{tabular}

a. Dependent Variable: Motivasi_Kerja

Sumber : Hasil Pengolahan Data, 2015

Berdasarkan dari tabel di atas menunjukan nilai koefisien jalur antara variabel Kompetensi dan Kompensasi terhadap Motivasi Kerja. Tabel 4.5 menunjukkan bahwa hasil perhitungan korelasi dengan model 2-tailed atau dua sisi diperoleh hubungan antara variabel Kompetensi dan Kompensasi sebesar 0,845 .

Pengaruh secara bersamaan dari variabel Kompetensi $\left(\mathrm{X}_{1}\right)$ dan Kompensasi $\left(\mathrm{X}_{2}\right)$ terhadap Motivasi Kerja (Y) dapat dilihat dalam tabel dibawah ini:

\section{Tabel 4.6}

Pengaruh Langsung dan Tidak Langsung Variabel (X) terhadap (Y)

\begin{tabular}{|l|l|l|l|l|l|}
\hline \multirow{2}{*}{$\begin{array}{l}\text { Variab } \\
\text { el }\end{array}$} & \multirow{2}{*}{$\begin{array}{l}\text { Koefisien } \\
\text { Jalur }\end{array}$} & $\begin{array}{l}\text { hengaru } \\
\text { langsun } \\
\text { g }\end{array}$ & \multicolumn{2}{|l|}{$\begin{array}{l}\text { Pengaruh } \\
\text { tidak langsung }\end{array}$} & \begin{tabular}{l} 
Subtotal \\
Pengaru \\
\cline { 3 - 6 }
\end{tabular} \\
\cline { 3 - 6 } & & $\mathbf{X}_{1}$ & $\mathbf{X}_{2}$ & $\mathbf{h}$ \\
\hline $\mathrm{X}_{1}$ & 0.492 & 0.242 & - & 0.150 & 0.392 \\
\hline $\mathrm{X}_{2}$ & 0.362 & 0.131 & 0.150 & - & 0.281 \\
\hline Total & & & & & $\mathbf{0 . 6 7 3}$ \\
\hline
\end{tabular}




\section{Pengaruh Variabel Lain}

$\mathbf{0 , 3 2 7}$

Sumber : Hasil Pengolahan Data, 2015

Berdasarkan tabel di atas, terlihat bahwa variabel Kompetensi mempunyai pengaruh langsung terhadap variabel Motivasi Kerja sebesar 0,242, pengaruh tidak langsung melalui hubungannya dengan variabel Kompensasi sebesar 0,150. Sedangkan, variabel Kompensasi mempunyai pengaruh langsung terhadap variabel Motivasi Kerja sebesar 0,131, pengaruh tidak langsung melalui hubungannya dengan variabel Kompetensi sebesar 0,150.

Total pengaruh dari variabel bebas : Kompetensi $\left(\mathrm{X}_{1}\right)$ dan Kompensasi $\left(\mathrm{X}_{2}\right)$ terhadap Motivasi Kerja (Y) dinyatakan oleh besaran koefisien determinasi $\left(\mathrm{R}_{\mathrm{YX}}\right)^{2}$ sebesar 0,673. Efek dari faktor lain terhadap Motivasi Kerja ditunjukkan oleh nilai $\rho y \varepsilon=0,327$ atau sebesar $32,7 \%$.

Berikut ini adalah tabel hasil pengolahan data model summary :

\section{Tabel 4.57}

\section{Iodel Summary}

\begin{tabular}{|l|l|l|l|l|l|}
\hline Model & $\mathbf{R}$ & R Square & $\begin{array}{l}\text { Adjusted } \\
\text { Square }\end{array}$ & $\begin{array}{l}\text { Std. Error of } \\
\text { the Estimate }\end{array}$ \\
\hline 1 & $.821^{\mathrm{a}}$ & .675 & .671 & 4.335 \\
\hline
\end{tabular}

a. Predictors: (Constant), Kompensasi, Kompetensi

Sumber : Hasil Pengolahan Data, 2015

Berdasarkan tabel di atas terlihat bahwa model summary Kompetensi dan Kompensasi terhadap Motivasi Kerja sebesar 0,675, hal ini berarti Kompetensi dan Kompensasi memiliki kontribusi terhadap Motivasi Kerja sebesar $67,5 \%$ sedangkan sisanya 32,5\% merupakan kontribusi variabel lain yang tidak diteliti.

\section{E. PENUTUP}

\section{KESIMPULAN}


Berdasarkan hasil analisis dari pembahasan yang tidak dikemukakan pada bab sebelumnya, maka dapat ditarik kesimpulan sebagai berikut :

1). The Kompetensi pada PT Hamatetsu Indonesia dengan 11 butir pernyataan terhadap variabel Kompetensi berdasarkan hasil rata-rata kuisioner menunjukan bahwa setuju mengenai Kompetensi yang sudah ada di perusahaan. Adapun indikator yang masih berada dibawah skor rata-rata dalam variabel Kompetensi yaitu : pengetahuan tentang teknis, kondisi kerja, dan aktifitas kerja. Penelitian dalam hal tersebut apabila dibiarkan akan mempengaruhi Kompetensi karyawan.

2). Kompensasi pada PT Hamatetsu Indoesia dengan 12 butir pernyataan terhadap variabel kompensasi berdasarkan hasil rata-rata kuisioner menunjukan bahwa karyawan cukup setuju mengenai Kompensasi yang ada di perusahaan. Adapun indikator yang masih berada dibawah skor rata-rata dalam variabel Kompensasi yaitu : Tunjangan Kesehatan dan Asuransi. Penelitian dalam hal tersebut apabila dibiarkan akan mempengaruhi Kompensasi karyawan.

3). Motivasi Kerja Karyawan pada PT Hamatetsu Indonesia dengan 13 butir pernyataan terhadap variabel Motivasi Kerja berdasarkan hasil rata-rata kuisioner menunjukan bahwa karyawan setuju mengenai Motivasi Kerja yang ada di perusahaan. Adapun indikator yang masih berada dibawah skor rata-rata dalam variabel Motivasi Kerja yaitu : memikul resiko, kerja kelompok, pengaruh dan kekuasaan. Penelitian dalam hal tersebut apabila dibiarkan akan mempengaruhi Motivasi Kerja karyawan.

4). Koefisien korelasi diantara variabel bebas yaitu hubungan antara Kompetensi dan Kompensasi didapat nilai 0.845 yang berarti mempunyai tingkat hubungan yang sangat kuat dan searah karena nilainya positif serta memiliki hubungan yang signifikan antara Kompetensi dan Kompensasi.

5). Koefisien jalur variabel Kompetensi secara parsial terhadap Motivasi kerja adalah sebesar 0.392 dan koefisien jalur variabel Kompensasi terhadap Motivasi kerja adalah sebesar 0.281. Dengan demikian dapat 
disimpulkan bahwaKompetensi dan Kompensasi memiliki pengaruh parsial terhadap Motivasi kerja.

6). Variabel Kompetensi dan Kompensasi secara simultan mempunyai pengaruh yang positif dan signifikan terhadap Motivasi kerja karyawan pada PT Hamatetsu Indonesia. Pengaruh Kompetensi dan Kompensasi terhadap Motivasi kerja sebesar 0.675 atau 67.5\%. Hal ini menunjukan bahwa Kompetensi dan Kompensasi memiliki kontribusi terhadap Motivasi kerja sebesar 67.5\%, sedangkan sisanya $32.5 \%$ merupakan kontribusi variabel lain $(\mathcal{E})$ yang tidak diteliti seperti Lingkungan Kerja, Pengembangan SDM, Budaya Organisasi dan kinerja.

\section{SARAN}

Berdasarkan hasil kesimpulan diatas, maka dapat disampaikan saran yang bermanfaat bagi perusahaan antara lain :

1). Penerapan Kompetensi pada PT Hamatetsu Indonesia telah berjalan dengan baik karena banyak tanggapan dari responden menyatakan setuju mengenai Kompetensi yang sudah ada di perusahaan. Berdasarkan hal tersebut penting bagi perusahaan untuk mampu meningkatkan kompetensi perusahaan dengan cara memberi pembelajaran kembali kepada karyawan secara terus menerus dan menempatkan karyawan sesuai dengan kompetensinya masing-masing agar perusahaan dapat lebih berkembang dan bersaing dengan perusahaan yang lain.

2). Pemberian Kompensasi pada PT Hamatetsu Indonesia telah dilakukan cukup baik karena dari hasil kuisioner banyak tanggapan dari responden menyatakan setuju tetapi ada beberapa responden yang menyatakan tidak setuju dikarenakan Tunjangan kesehatan dan asuransi yang harusnya sesuai dengan peraturan kerja bersama (PKB) antara karyawan dengan perusahaan. Berdasarkan hal tersebut maka perusahaan harus memberikan hak karyawan sesuai dengan peraturan 
kerja bersama (PKB) yang telah disepakati oleh perusahaan dan karyawan.

3). Pelaksanaan Motivasi kerja karyawan pada PT Hamatetsu Indonesia telah dilakukan dengan baik karena dari hasil kuisioner banyak tanggapan dari responden menyatakan setuju mengenai Motivasi kerja. Berdasarkan hal tersebut penting bagi perusahaan untuk mampu meningkatkan motivasi kerja karyawan misalnya, dengan cara memberikan bonus bagi karyawan yang tertib dan tidak pernah absen, tetap memberikan cuti tahunan bagi karyawan, agar para karyawan bisa memaksimalkan dalam mengerjakan pekerjaannya, perusahaan bisa memberikan kesempatan bagi karyawan untuk bekerja sama dengan karyawan lain, perusahan mengadakan kegiatan-kegiatan yang dapat menjalin rasa kekeluargaan atau mengadakan kegiatan yang dapat menghilangkan kejenuhan karyawan terhadap pekerjaanya, seperti yang sudah dilakukan oleh perusahaan misalnya, berwisata, olah raga dan sebagainya.

4). Hubungan Kompetensi dan kompensasi pada PT Hmatetsu Indonesia diperoleh nilai sebesar 0.845 yang berarti mempunyai tingkat hubungan yang sangat kuat dan searah karena nilainya positif. Oleh karena itu Kompetensi dan Kompensasi yang telah dilaksanakan oleh perusahaan harus dipertahankan karena kedua faktor tersebut memiliki pengaruh yang kuat dalam meningkatkan Motivasi kerja karyawan pada perusahaan.

5). Pengaruh parsial Kompetensi $=0.492$ dan Kompensasi $=0.362$ terhadap Motivasi kerja karyawan pada PT Hamatetsu Indonesia. Berdasarkan hasil tersebut perusahaan disarankan untuk meningkatkan Kompetensi yang telah ada seperti memberi kesempatan kepada karyawan agar meningkatkan kemampuan dan keterampilan berkaitan dengan pelaksanaan tugas, pimpinan beserta manajemen bersedia membantu karyawan yang mengalami kesulitan dalam menyelesaikan tugas serta meningkatkan solidaritas antar sesama rekan kerja melalui kegiatan-kegiatan keakraban dan untuk motivasi, disarankan untuk 
pimpinan selalu memberikan motivasi secara berkala ataupun terus menerus sebagai pemberian semangat dan pantang menyerah dalam menjalankan pekerjaan.

6). Pengaruh simultan Kompetensi dan Kompensasi terhadap Motivasi kerja karyawan memiliki kontribusi sebesar $67.5 \%$ sedangkan sisanya $32.5 \%$ merupakan kontribusi variabel lain yang tidak diteliti. Maka untuk penelitian selanjutnya disarankan untuk memperluas penelitian dengan cara menambah variabel penelitian agar perusahaan dapat menetapkan kebijakan yang lebih efektif bagi peningkatan kinerja karyawan.

\section{F. DAFTAR PUSTAKA}

\section{$\underline{\text { BUKU }}$}

Edy Sutrisno,.2012. Manajemen Sumber Daya Manusia : Jakarta : Kencana Prenada media Group.

Hadari Nawawi,. Manajemen Sumber Daya Manusia. Yogyakarta : Gajah Mada University Press

Malayu S.P.Hasibuan,.2005. Manajemen Dasar, Pengertian, dan Masalah.Jakarta : Bumi Aksara

Malayu S.P.Hasibuan,.2013. Manajemen Sumber Daya Manusia.Jakarta : Bumi Aksara

Malayu S.P.Hasibuan,.2010. Organisasi dan Motivasi.Jakarta : Bumi Aksara

M.Kadarisman, 2012. Manajemen Kompensasi. Jakarta : PT Raja Grafindo Persada

Sugiyono.2011. Metode Penelitian Kuantitatif Kualitatif dan R\&D. Bandung : Alfabeta

Sudarmanto.2014. Kinerja dan pengembangan kompetensi SDM. Jakarta : Pustaka Pelajar.

Sondang Siagian,.2005. Teori Motivasi dan Aplikasinya. Jakarta : PT Rajagrafindo Persada. 
Wibowo.2011. Budaya Organisasi. Jakarta : PT Rajagrafindo Persada.

Winardi, 2011. Motivasi Pemotivasian dalam manajemen. Jakarta : PT Rajagrafindo Persada.

\section{INTERNET}

Diakses pada tgl 13 Januari 2015 (20.33)

http://digilib.esaunggul.ac.id/public/UEU-Master-2574-Kristina_Nugi_K_2010-

01-041.pdf

Diakses pada tgl 13 Desember 2014 (16.15)

http://repository.widyatama.ac.id/xmlui/bitstream/handle/123456789/2266/Fajar\%

20Kurniadi.pdf?sequence $=1$

Diakses pada tgl 13 Januari 2015 (20.17)

http://eprints.undip.ac.id/39988/1/MURBIJANTO.pdf 